\title{
Evaluation of MPAPE Landfill Standard in FCT Abuja, Nigeria
}

\author{
Magaji J.Y. \\ Department of Geography and Environmental Management, University of Abuja \\ DOI: 10.29322/IJSRP.10.06.2020.p10273 \\ http://dx.doi.org/10.29322/IJSRP.10.06.2020.p10273
}

\begin{abstract}
Landfills have served a key role in the management of solid wastes and are likely to continue to be an important component of the waste management system. When they are not properly constructed, they become more hazardous than tonnes of waste scattered around. This study was set to evaluate Mpape waste dump, this is with the view to verify if the landfill was scientifically constructed. The information was sourced through both Primary and Secondary sources. The primary sources include the use of checklist, observation and interviews, while secondary sources are the set standard by EPA and AEPB relevant documents. The data used was qualitative in nature, where description of the nature of the landfill was made. The results of the evaluation revealed that of all the selected criteria used in the study, none of them was met by the landfill standard. The dumpsite was sited in water shed, there was no liner used, no provision for leachete collection facility. Poor covering after compaction leading to erosion and released of heavy concentrated leachate. It is therefore recommended that there should be regular monitoring and treatment of the stream water before discharging the water for public consumption. Further studies to be conducted on the impacts of the dumpsite on water, soils and air quality.
\end{abstract}

Index Terms- Evaluation, Landfill standard, liner, leachate, Mpape dumpsite

\section{INTRODUCTION}

$\mathrm{T}$ he management of solid waste is one of the major challenges faced by any developing country. In recent years, the increase in the urban population, together with their changes in production and consumption patterns, the improvement in people standard of living and the proliferation of suburbs have led to a significant increase in the volume of solid waste in Nigeria. Systematic waste collection practice is a major bottleneck, yet it is a major factor that contributes to the success of any waste management program. The low rate of collection causes open dumps and the dispersion of garbage in the streets.

Landfills have served a key role in the management of solid wastes and are likely to continue to be an important component of the waste management system. The implementation of the waste management hierarchy of waste avoidance, reuse, recycling, recovery of energy, treatment, containment and finally waste disposal has resulted in significant diversion of waste from landfill. Disposal of materials to landfill is the least preferred management option; however, landfills will continue to be required in the future to manage those wastes that cannot currently be practicably removed from the waste stream. Today's landfills must not leave an unacceptable environmental legacy for our children to address. As long as landfilling remains part of our waste management strategy, best-practice measures must be adopted to ensure that landfills are acceptable to the public.

Inappropriate and unplanned siting of landfill facilities or lack of engineered protection measures can result in a number of social, economic, and environmental concerns such as release of leachate to the environment, emission of toxic and explosive landfill gases, dispersion of dust and odour as well as visual landscaping problems for adjacent residential areas (Looser et al. 1999; Kim et al. 2009; Moghaddas and Namaghi 2011). Undoubtedly, ideal and precise landfill site selection can mitigate various issues concerned with waste disposal. Therefore, selecting landfill sites that meet the environmental regulations, social, economic, technical factors and reduce the undesired impacts of current practices is the main priority for MSW management.

Landfill site selection is a challenging task as it involves multiple factors such as, technical, environmental, geo-logicalhydrogeological, operational, economic, social and political (Sumathi et al. 2008; Goorah et al. 2009; Gorse- vski et al. 2012). The criteria used to determine the importance of these characteristics are often contradictory. Many a times attempts for siting new landfills in the region have been rejected mostly by public opposition due to the lack of information given to the public, that creates the "not in my back yard" (NIMBY) syndrome for siting new landfills (Chiueh et al. 2008). The environmental regulations and increasing amounts of waste production further complicate the process with critical factors, which mechanically mask unsuitable areas, leaving very less options to be assessed. With such conflicting criteria, it is often impossible to find the 'optimal' landfill site. Thus, the selection of the suitable landfill site turns out to be a complex multi-criteria assessment and decision-making problem. Cheng et al. (2002) addressed the need for using multi-criteria decision making (MCDM) methodologies in solid waste management systems because these systems can have complex and conflicting impacts on different stakeholders. Due to uncertainty and impreciseness of available information, apart from the ambiguity of human preferences, it is difficult to get accurate numerical values for the evaluation criteria.

Landfill is the oldest method of urban waste disposal and the last link in the chain of their management. It was always considered as a best possible treatment of any domestic waste due to its low cost. However, the process of landfilling has completely changed due to changes in regulations, increasingly problematic environmental issues and the emergence of new technologies that 
are both reliable and economical. In Europe, landfills concern only the fraction of waste that cannot be valued by reuse or recycling. Kontos et al. (2005) took into consideration four criteria (social, environmental, technical, and economic) and eleven sub-criteria for the delineation of potential landfill sites. Eiselt, (2006) considered minimum transportation costs for selecting ideal MSW landfill sites using mixed integer linear programming (MILP). Simsek et al. (2006) presented a method considering ground water risk. i.e., the vulnerability of ground water to contamination. Their method took into consideration five factors, namely depth of ground water, upper layer lithology, permeability of unsaturated zone, impermeable layer thickness and topographic slope.

\section{REQUIREMENTS FOR A STANDARD LANDFILL}

The criteria for siting a landfill as prescribed by USEPA. The "Criteria" is a guidance document for MSW landfills provided by the Ministry of Environment and is to be considered during the setting of legal standards specified within SWMPs, operational certificates and permits. The director may require additional information and/or specify legal standards that are more or less stringent than these "Criteria". Information regarding the waste discharge authorization process is available on the Ministry of Environment website. Compliance with the "Criteria" does not relieve the owner/operator from the requirements of any other Acts, Regulations, including regulations under the Environmental Management Act, or By-Laws.

Siting Criteria: Proper siting of a landfill site is one of the most important aspects of environmental protection. Siting must consider the physical conditions of a site, the remoteness of the area, the existing and planned land uses in proximity, the sensitivity of the receiving environment and the size of the landfill site. From an environmental perspective, the principal objective of site selection is to identify a suitable location for a landfill to safeguard public health, have minimal impact on the environment, and provide for long term isolation of MSW deposited in the landfill site. Distance requirements stated in the following sections are Ministry criteria, unless noted otherwise.

Land Use: The landfill footprint must not be located within $500 \mathrm{~m}$ of an existing or planned sensitive land use. A planned sensitive land use is one that has been identified as an allowed use in a regional growth management plan, official community plan or zoning by-law but has not yet been established. Sensitive land uses include, but are not limited to: schools, residences, hotels, restaurants, cemeteries, food processing facilities, churches, and municipal parks. Land uses such as heavy industry, forestry operations, aggregate extraction/mining, railways/rail yards, etc. are not considered sensitive land uses.

Heritage and Archeological Sites: The landfill footprint is recommended not to be located within $100 \mathrm{~m}$ of a heritage or archaeological site. Landfill siting is also subject to the requirements of the $\mathrm{BC}$ Heritage Conservation Act administered by the Archaeology Branch of the British Columbia Ministry of Forests, Lands and Natural Resource Operations. The Branch and website should be consulted for requirements.

Buffer zone: The buffer zone between the landfill footprint and the landfill site boundary shall be a minimum of $50 \mathrm{~m}$, of which the $30 \mathrm{~m}$ closest to the landfill site boundary shall be reserved for natural or landscaped screening (berms and/or vegetative screens). Only the $20 \mathrm{~m}$ buffer closest to the landfill footprint shall be used for access roads, surface water management works, leachate management, landfill gas management and monitoring works, firebreaks, and other ancillary works as required.

Water Supply Sources: The landfill footprint shall be a minimum distance of $300 \mathrm{~m}$ from a water supply well or water supply intake and a minimum 500m from municipal or other high capacity water supply wells.

Gullies and Depressions: The landfill footprint shall not be located in a gully or depression that acts as a point of water collection during rainfall events unless acceptable diversion works are provided such as interception ditching or other diversion measures are undertaken. Diversion of water through culverts beneath the landfill footprint is not allowed.

Faults and Unstable areas: The landfill footprint shall not be located within $100 \mathrm{~m}$ of a geologically unstable area. A geologically unstable area is defined as a location where natural or man-made features pose a substantial risk to the integrity of the landfill environmental control systems or global stability of the fill. Specifically, the landfill footprint must not be located within 100m of:

- A Holocene fault.

- A known active or historic landslide.

- Areas underlain by weak or collapsible soils, karst limestone, frozen mineral soil or muskeg with an active layer, or underground mine workings.

- Areas prone to debris movement (landslide paths, avalanche paths, alluvial fans).

- A location at risk of being impacted by tsunami.

Environmentally Sensitive Areas: The landfill footprint must not be located within $100 \mathrm{~m}$ of an environmentally sensitive area such as:

- A national, provincial or regional park.

- A wildlife management area as designated under Section 4 of the provincial Wildlife Act.

- A critical wildlife area or wildlife sanctuary designated under Section 5 of the provincial Wildlife Act.

- $\quad$ A land acquired and administered under Section 3 of the provincial Wildlife Act.

- An ecological reserve designated under the provincial Ecological Reserve Act.

- A bird sanctuary designated under the regulations pursuant to the federal Migratory Birds Convention Act.

- A wildlife area designated under the federal Wildlife Act.

- A wetland.

- The habitat of rare, threatened or endangered species under federal and/ or provincial Species at Risk legislation.

Floodplains and Shorelines: A landfill footprint shall not be located in a floodplain and it shall not be located within $100 \mathrm{~m}$ of the sea level maximum high tide or seasonal high watermark of an inland lake shoreline.

Depth of Water Table: The landfill base shall be a minimum $1.5 \mathrm{~m}$ above "groundwater" at all times. The separation 
distance shall consider the hydrogeologic conditions at the site including the hydraulic capacity of the underlying soils.

Performance Criteria: Performance criteria in this guidance document ensure adequate protection of human health and environment. All assessments, designs, reports and plans, developed under this guidance document must demonstrate how they will satisfy performance criteria. All the documents must be prepared under the supervision of, and certified by, a Qualified Professional.

Landfill Gas Management: Soil gas concentrations at the landfill site boundary must not exceed the lower explosive limit of methane ( 5 percent by volume) at any time. Combustible gas concentrations measured in on-site buildings must not exceed 20 percent of the lower explosive limit of methane ( $1 \%$ by volume) at any time. Landfill Gas must also be managed in accordance with all migration and health and safety requirements. LFG emissions must be managed such that all federal, provincial, and local ambient air quality objectives and standards are not exceeded. This regulation requires that all landfills having more than 100,000 tonnes of waste in place, or receiving more than 10,000 tonnes of waste per year, are to submit a Landfill Gas Generation Assessment Report. Landfills determined to be generating more than 1,000 tonnes of methane per year are required to prepare a Landfill Gas Management Facilities Design Plan and to have a landfill gas management system in place four years after the plan submission. Landfill gas management systems are to be designed to maintain 75 percent collection efficiency as determined by the Ministry of Environment Gas Generation Model.

Nuisance: A landfill shall be operated and maintained so as not to create a "nuisance" including but not limited to dust, noise, litter, odour, vectors and/or wildlife attraction.

Design criteria: This section of the "Criteria" presents the design objectives and minimum requirements for a landfill site and the environmental control systems to be implemented on the site. Landfills must be designed to protect the environment and satisfy all the applicable criteria set out in this document.

Service Life and Contaminating Lifespan: A landfill site must be designed such that the service life of the facilities exceeds the contaminating lifespan. The site layout shall be designed to satisfy all criteria including the siting criteria, and minimise environmental impacts.

The final stage of disposal in waste management is landfilling. Normally landfilling should come after Reuse and Recycling (WRAP, 2012), but in most parts of Africa such as Nigeria, these stages are not as popular or deemed as essential as landfilling. Landfilling has been the most common method of solid waste disposal generated by different communities for many years (Komilis et al, 1999). It has been the principal method of the municipal solid wastes' elimination in the recent decades because it is the simplest practice and the most economical of this type of wastes' storage in a lot of countries, particularly in the developing countries (Breza-Boruta, et al, 2016).

According to Agunwamba (1998), in 1998 there were only two landfills in Nigeria. By 2007, the situation had not totally changed as Abuja, the capital city of Nigeria, did not have sanitary landfills for waste disposal, instead deposited their solid waste at the Mpape dumpsite (Imam et al., 2008).

Unfortunately, open landfills caused serious sanitary risks by the lodging of different stray animals and the proliferation of insect vectors of a lot of diseases; they also present nuisance and considerable environmental impacts by the production of both leachate and biogas (Aronsson, et al, 2010). The leachate conveys an important pollution load essentially formed of heavy metals, organic matter, and important community of pathogenic bacteria: by leaching and infiltration through the ground, it begets an organic, bacteriological, and heavy metal pollution of soils, surface water, and ground water i.e phreatic zone, (Mohee and Soobhany, 2014).

Landfills pose a big problem to the environment in which during landfill operations, different kinds of hazards including gas and leachate are produced (Modin, (2012). The leachate problem is worsened by the fact that many landfills lack an appropriate bottom liner or collection system; increasing the possibility of dissipation of leachate through the landfill layers to contaminate ground water (Kanmani and Gandhimathi, 2013). It can cause serious pollution problems when it gets in contact with the surrounding soil, surface water and ground water leading to detrimental effects on living organisms.

Thus, Leachate formation now is one of the greatest problems that need to be managed properly (Adeolu, et al., 2011). The leachate composition varies greatly from landfill to landfill depending on site specific characteristics. One of the most hazardous components in leachate is heavy metals. There is a growing concern regarding the buildup of heavy metals in soil and ground water. Different kinds of wastes are responsible for the presence of heavy metals in the landfills. Sources such as electronic waste, painting waste and used batteries increase heavy metals content in landfills (Adeolu, et al., 2011).

The recent increase in use and disposal of electronic devices like cell phones and computers raise the question about the quantity of metals they contain in waste disposal sites and their fate in the environment especially because such devices mainly contain lead, cadmium, mercury, arsenic, copper, zinc and others (Agamuthu, and Fauziah, 2010).

A number of cases of ground water pollution through continuous percolation of leachate in India and USA have been recorded (James, 1977 and Biswas, et al, 2010,). Many cases were probably undetected because people are not aware that their wells are contaminated (James, 1977). The information on the quality of landfill leachate in the Mediterranean region is limited. It is generally expected that there would not be much leachate generated from the landfills of arid climate. It is against this background therefore, the evaluation of landfill is set to provide a substantial contribution to a better understanding of the waste dump situation and can lead to more efficient management of the sites based on the evaluation analysis.

\section{MATERIALS AND METHODS}

The Mpape dumpsite was the major site used as landfill for the Federal Capital Territory before relocating to Gosa, around 2006 when the site was filled up. It is located at the Northeastern edge of the Gwagwa plains, along Aso-Bwari hills by the Kubwa expressway near the tipper garage of Mpape, within the watershed of the River Usuma Basin. The Federal Capital Territory (FCT) Abuja is located between latitudes $8^{\circ} 25^{\prime}$ and $9^{\circ} 25^{\prime}$ north of the equator and longitudes $6^{0} 45^{\prime}$ and $7^{0} 45^{\prime}$ east of Greenwich meridian (Figure1). It occupies an area approximately $8,000 \mathrm{~km}^{2}$ 
and occupies about $0.87 \%$ of Nigeria. The territory is situated within the region generally referred to as the Middle Belt
(Mabogunje, 1977), and is bordered on all sides by four states namely Kogi, Niger, Kaduna, and Nassarawa.

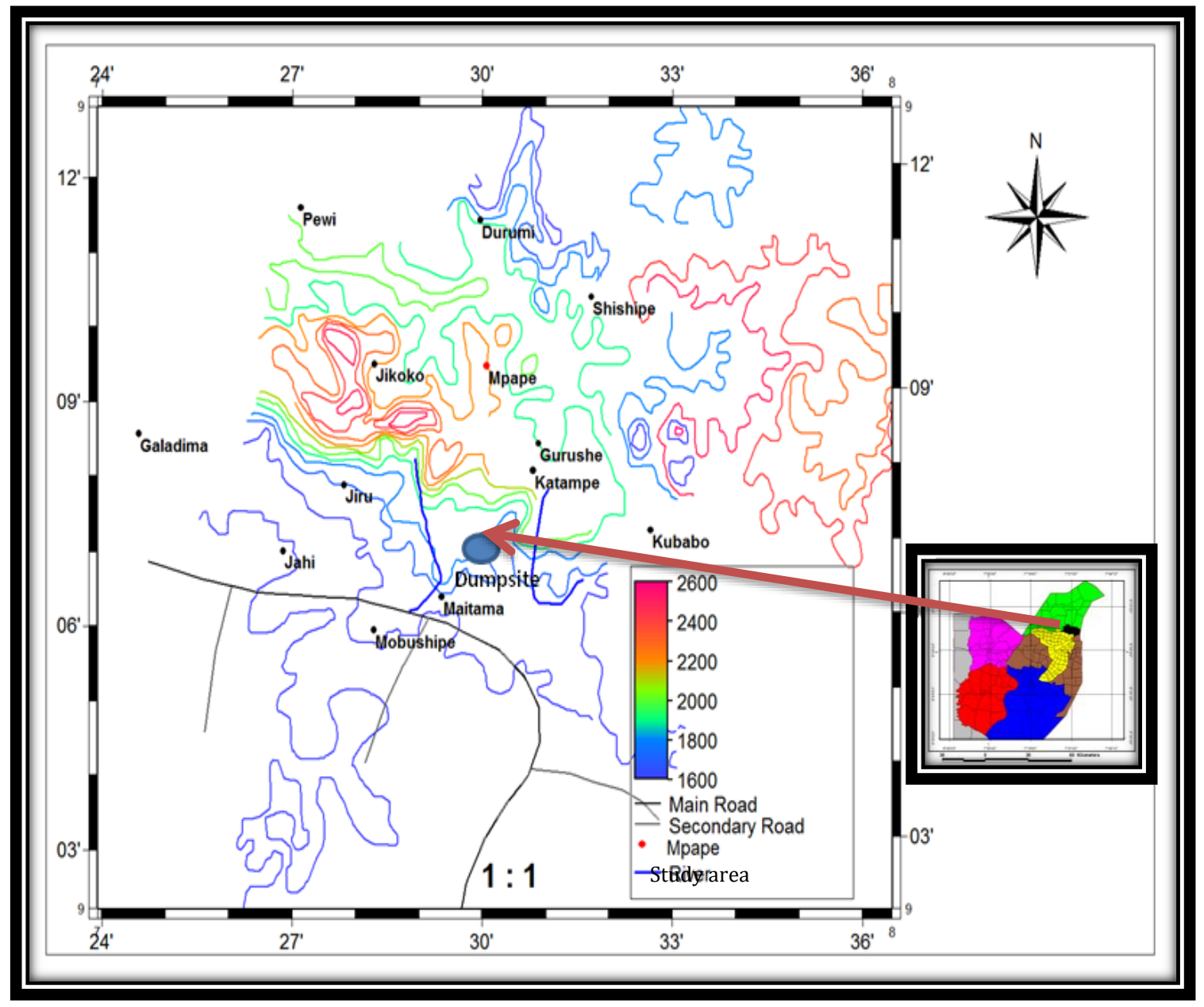

Figure 1: Location of Mape Dumpsite in the FCT.

Source: Modified from diverse sources by the Author, (2018)

The Federal Capital consists of a number of distinct physiographic regions basically of two types, the hills and the plains. The elevations of these hills range from about $100 \mathrm{~m}$ to about $300 \mathrm{~m}$ in the more rugged areas. The landfill is situated at the upper part of the plains. The influence of parent materials on the soil of FCT stem from the fact that two parent materials, namely, crystalline rocks of the basement complex and Nupe Sandstone are the surface from which they are formed. The soils of the FCT, for the purpose of easy identification is described along six major land systems, namely, the undulating Gwagwalada plains, the Abuja dissected plains, the Kau plains, the undulating Kuje plains, the Iku and the Robo plains (Alhassan, 2000). The alluvial complexes of the territory are contained in all the stream channels which are made up of gleysols which are very fertile and occur dominantly in Abaji Area Council of the FCT. The soils of the plains are mostly sandy and sandy-loam.

The Federal Capital Territory records the highest temperature during the dry season months, which are generally cloudless. The maximum temperature occurs in the month of March with amounts varying from $37^{\circ} \mathrm{C}$ in the Southwest to about $30^{\circ} \mathrm{C}$ in the Northeast. This also coincides with the period of high diurnal ranges of temperature which can drop to as low as $17^{\circ} \mathrm{C}$, and by August, diurnal temperature rarely exceeds $7^{\circ} \mathrm{C}$.

\section{Type and sources of data}

The data used for this study was qualitative in nature and was sourced through both primary and secondary sources. The primary sources of data include a checklist designed in-line with the basic criteria for siting and constructing a landfill site, observation, and interview with some key personnel of solid waste management department of Abuja Environmental Protection Board. The secondary sources include the documents on the Standard criteria for siting a landfill.

\section{RESULTS AND DISCUSSION}

\section{Assessment of Landfill Standards}

Mpape Dumpsite was assessed in relation to the United State Environmental Protection Landfill standards to see the level of compliance with the requirements for a standard landfill. The indicators considered are: Location restrictions, Liners, Operating 
practices, Groundwater monitor, Closure and post closure care,

Corrective action and financial assurance.

Table 1: Landfill Standard

\begin{tabular}{|c|c|c|}
\hline Federal Landfill Standard & Mpape Dumpsite standard & Remarks \\
\hline $\begin{array}{l}\text { Location restrictions: Ensure that } \\
\text { landfills are built in suitable geological } \\
\text { areas away from faults, wetlands, flood } \\
\text { plains, or other restricted areas. }\end{array}$ & $\begin{array}{l}\text { The Mpape Dumpsite is located in a watershed area, } \\
\text { near a quarry site. (Plates } 1 \text {, and 2), at the foot of Aso- } \\
\text { Bwari hills. }\end{array}$ & $\begin{array}{l}\text { Never met the } \\
\text { requirement. }\end{array}$ \\
\hline $\begin{array}{l}\text { Liners: are geomembrane or plastic } \\
\text { sheets reinforced with two feet of clay } \\
\text { on the bottom and sides of landfills. }\end{array}$ & $\begin{array}{l}\text { There was no engineering construction on the site, as } \\
\text { regards to protection of both surface and ground water } \\
\text { contamination. (Plates } 2 \& 3 \text { ). }\end{array}$ & $\begin{array}{l}\text { Never met the } \\
\text { requirement. }\end{array}$ \\
\hline $\begin{array}{l}\text { Operation practices: such as } \\
\text { compacting and covering waste } \\
\text { frequently with several inches of soil } \\
\text { help to reduce odour, control litter, } \\
\text { insects, and rodents; and protect public } \\
\text { health. }\end{array}$ & $\begin{array}{l}\text { Compacting was done on daily bases and no covering } \\
\text { of waste until the site was filled up before covering was } \\
\text { done. Now erosion is exposing the covered waste. } \\
\text { Above all the site has unpleasant odour which attracts } \\
\text { insects, rodents, and expose the public to health risk. }\end{array}$ & $\begin{array}{l}\text { Never met the } \\
\text { requirement. }\end{array}$ \\
\hline $\begin{array}{l}\text { Groundwater monitor: Requires } \\
\text { testing groundwater to determine } \\
\text { whether waste materials have escaped } \\
\text { from the landfill. }\end{array}$ & $\begin{array}{l}\text { In this case, borehole was the only provision been made } \\
\text { to monitor the ground water. But the fact is that it is not } \\
\text { functioning as proposed. There are evidences of } \\
\text { leachates coming out of the dump. (Plates } 3 \& 4 \text { ). }\end{array}$ & $\begin{array}{l}\text { Never met the } \\
\text { requirement. }\end{array}$ \\
\hline $\begin{array}{l}\text { Leachate collection system: The } \\
\text { leachate collection system is an integral } \\
\text { component of the overall landfill liner } \\
\text { system meant to collects and treat } \\
\text { leachetes before discharging. }\end{array}$ & $\begin{array}{l}\text { Since there was no engineering construction of landfill, } \\
\text { there is no provision of leachetes collection system in } \\
\text { the landfill. }\end{array}$ & $\begin{array}{l}\text { Never met the } \\
\text { requirement. }\end{array}$ \\
\hline $\begin{array}{l}\text { Closure and post closure care: include } \\
\text { covering landfills and providing long- } \\
\text { time care of closed landfills. }\end{array}$ & $\begin{array}{l}\text { This landfill was filled-up and just relocated to Gosa in } \\
\text { the year } 2007 \text {. The depth of the covering is very thin } \\
\text { that erosion is exposing the wastes, despite the } \\
\text { landscaping as a control measure. }\end{array}$ & $\begin{array}{l}\text { Never met the } \\
\text { requirement. }\end{array}$ \\
\hline $\begin{array}{l}\text { Corrective action: controls and cleans } \\
\text { up landfill releases and achieves } \\
\text { groundwater protection standards. }\end{array}$ & $\begin{array}{l}\text { As observed in plate } 3 \text {, the leachates drains to the } \\
\text { surface water not even the underground water. }\end{array}$ & $\begin{array}{l}\text { Never met the } \\
\text { requirement. }\end{array}$ \\
\hline $\begin{array}{l}\text { Financial assurance: provides funding } \\
\text { for environmental protection during and } \\
\text { after landfill closure (i.e. closure and } \\
\text { post closure care) }\end{array}$ & $\begin{array}{l}\text { The site is currently being reclaimed and part is to be } \\
\text { used for Waste composting. }\end{array}$ & $\begin{array}{l}\text { Never met the } \\
\text { requirement. }\end{array}$ \\
\hline
\end{tabular}

Source: Field survey, 2018.

The result in Table 1 revealed that the landfill did not meet any of the selected criteria evaluated. This implies that the landfill might posed a lot of environmental degradation in the study area, as it was located in a water shed, without the use of liner, no leachate monitoring system, and erosion has already setting in. 

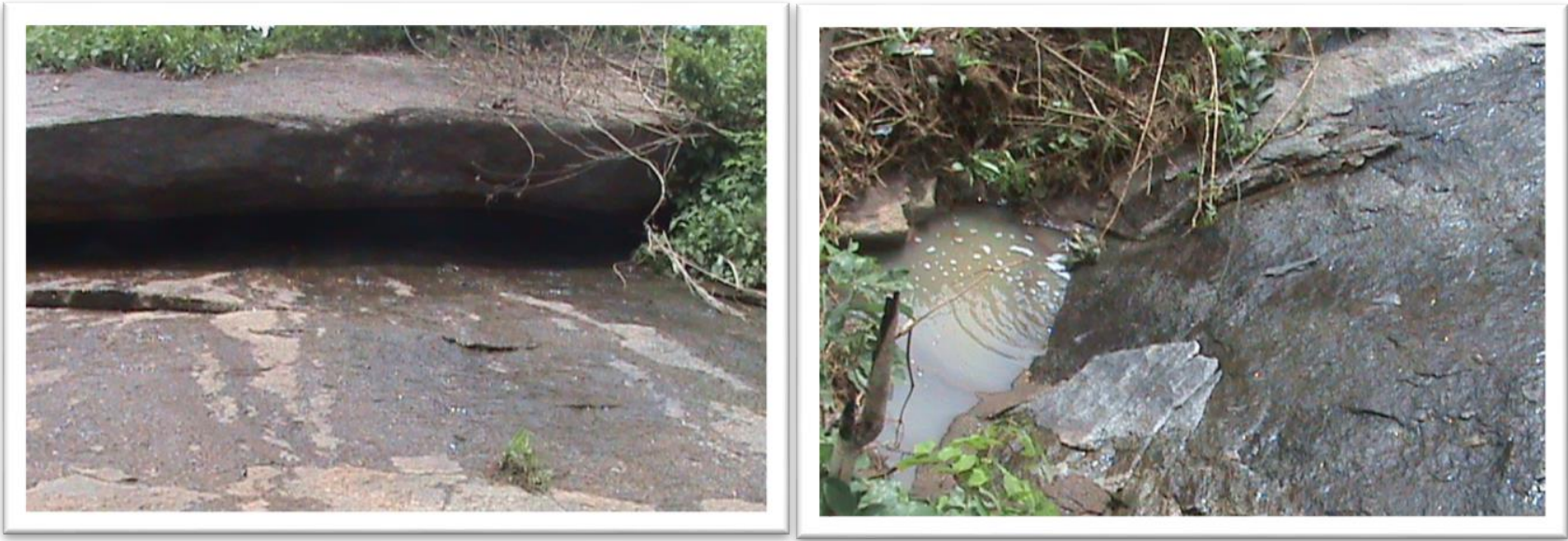

Plate 1: One of the sources and the stream around Plate 2: One of the sources of the stream the dumpsite around the dumpsite.

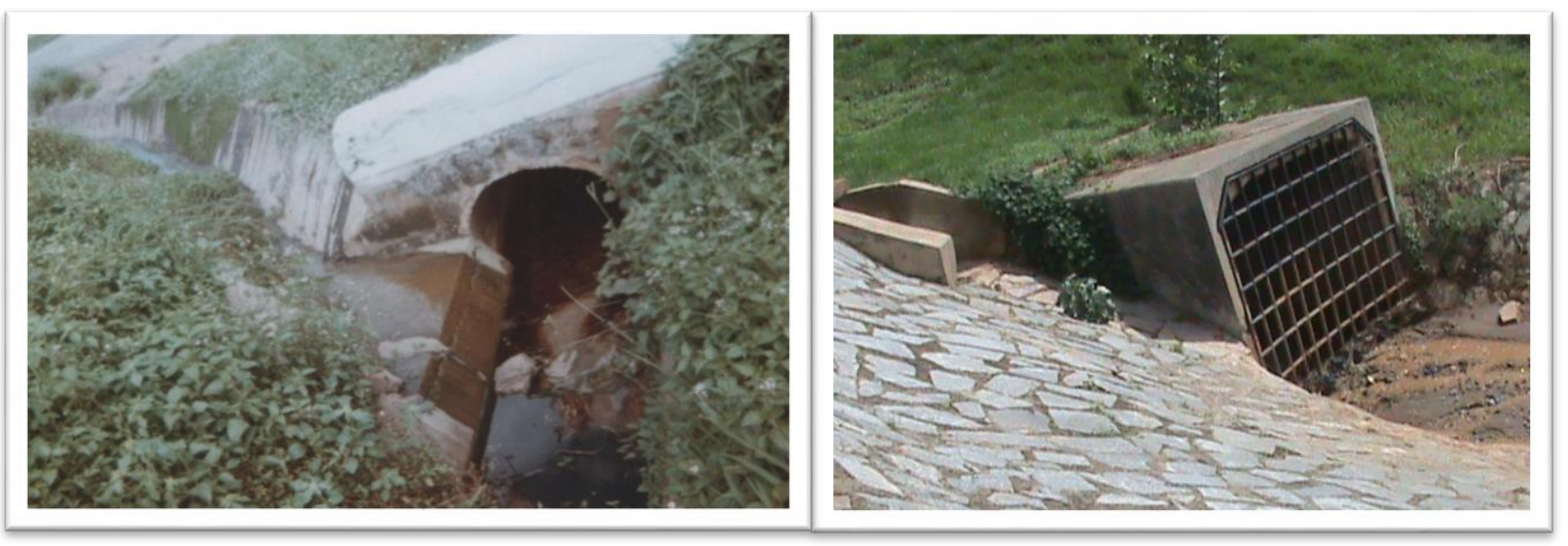

Plate 3: Leachates from dumpsite drained into the drainage channels to the stream.

\section{DISCUSSION OF RESULTS}

The results of the evaluation revealed that Mpape dumpsite was located in a water shed area, at the foot of highland where two streams (tributaries of River Usuma) derived their sources. Liner and leachate collection system. One of the requirements of sitting a Landfill is to ensure that landfills are built in suitable geological areas away from faults, wetlands, flood plains, or other restricted areas. This implies that the streams within this dumpsite might be polluted from source.

Investigation also revealed that the dumpsite was formally a quarry site which have a depression that the waste was used to fill in. the construction guide demands that a landfill supposed to have a Liner. Liners are geomembrane or plastic sheets reinforced with two feet of clay on the bottom and sides of landfills. The principal functions of a landfill liner system are to limit contaminant migration to groundwater and to control landfill gas migration. This is achieved by the landfill liner slowing the vertical and lateral seepage of leachate to allow its collection and removal by the leachate collection system and to contain landfill gas within the landfill for appropriate collection. The liner may also attenuate contaminants in leachate seeping through the liner. A further function of the liner is to control infiltration of groundwater. The implication of this situation is that the there is no control of leachates as such both the soils and water (surface and ground water) are not been protected. This can also affect both plants and aquatics present within the area. This was confirmed in a study by Magaji, (2012), where he discovered that plants grown within the area are contaminated.

Another requirement is the operation practices such as compacting and covering waste frequently with several inches of soils, which helps to reduce odour, control litter, insects, and rodents; and protect public health. The situation in the study area showed that Compacting was done on daily bases, but no covering of waste until the site was filled up before covering was done. Now erosion is exposing the covered waste. Above all the site has unpleasant odour which attracts insects, rodents, and expose the public to health risk, despite the closure of the site.

Groundwater monitor is another requirement for a standard Landfill, this involve testing the groundwater to determine whether waste materials have escaped from the landfill. In this case, two boreholes were drilled to enable monitoring the ground 
water. But the fact is that it is not functioning as proposed. There are visible evidences of leachates coming out of the dumpsite despite the concrete embankments (Plates $3 \& 4$ ).

The leachate collection system is an integral component of the overall landfill liner system. The design objectives of the leachate collection system are to ensure that it is able to drain leachate sufficiently that the leachate head above the liner is minimized, it should be resistant to chemical attack, and physical, chemical and biological clogging. To be able to be inspected and cleaned by readily available video inspection and pipe cleaning equipment. This system is absent in the study area.

Closure and post closure care include covering landfills and providing long-time care of closed landfills. This landfill was filled-up and relocated to Gosa in the year 2007. The depth of the covering is very thin that erosion is exposing the wastes, despite the landscaping as a control measure. Part of the site is said to be converted to composting section.

Financial assurance: provides funding for environmental protection during and after landfill closure (i.e. closure and post closure care). The site is currently being reclaimed and part is to be used for Waste composting.

\section{CONCLUSION AND RECOMMENDATIONS}

In conclusion, the Landfill was discovered not to satisfy any of the selected criteria used for the study. The dumpsite was located in water shed at the foot of Aso-Bwari hill, there was no liner used during the construction of the dumpsite as such, there was no provision for leachete collection facility. There was compaction but no regular covering. This is leading to erosion and released of heavy concentrated leachate into the major river running through the FCT where so many people make use of the water. The leachates from the dumpsite flow into the stream to the river, thereby contaminating the water.

Base on the foregone discussion, it is therefore recommended that; there should be EIA before siting a landfill to avoid further contamination. There should be regular monitoring and treatment of the stream water before discharging the water for public consumption. Further studies should to be conducted on the impacts of the dumpsite on water, soils and air quality.

\section{REFERENCES}

[1] Abuja Environmental Protection Board (AEPB, 2012): Federal Capital Territory, Nigeria

[2] Adeolu, A.O., Ada, O. V. Gbenga, A.A. and Adebayo, O.A. (2011): Assessment of groundwater contamination by leachate near a municipal solid waste landfill,\| African Journal of Environmental Science and Technology, vol. 5, no. 11, pp. 933-940, 2011.

[3] Agamuthu P. and Fauziah, S.H. (2010): Heavy metal pollution in landfill environment: A Malaysian case study,\| presented at 4th International Conference on Bioinformatics and Biomedical Engineering, 2010

[4] Agunwamba, J. C. (1998). Solid waste management in Nigeria: Problems and issues. Environmental Management, 25(2), 849-856

[5] Alhassan, M.M. (2000): "Soils of the FCT" In: Dawam, P.D. (Ed.) Geography of Abuja, Federal Capital Territory. Famous/Asanlu Publishers, Minna. pp 32-40.

[6] Aronsson, P. Dahlin, T. and Dimitriou, I. (2010): "Treatment of landfill leachate by irrigation of willow coppice - plant response and treatment efficiency," Environmental Pollution, vol. 158, no. 3, pp. 795-804, 2010.
[7] Biswas, B. Kumar, A. Babu, S. Bhattacharyya, S, and Chakrabarti, J. (2010): Studies on environmental quality in and around municipal solid waste dumpsite, $\|$ Journal of Resources, Conservation and Recycling, vol. 55, pp. 129-134.

[8] Breza-Boruta, B. Lemanowicz, J. and Bartkowiak, A. (2016): "Variation in biological and physicochemical parameters of the soil affected by uncontrolled landfill sites," Environmental Earth Sciences, vol. 75, no. 3, pp. 201-213, 2016.

[9] Cheng S., Chan C.W., Huang G.H. (2002): Using multiple criteria decision analysis for supporting decisions of solid waste management. J Environ Sci Health Part A 37(6):975-990

[10] Chiueh P.T. Lo S.L. Chang C.L. (2008): A GIS-based system for allocating municipal solid waste incinerator compensatory fund. Waste Management. 28(12):2690-2701

[11] Eiselt H.A. (2006): Locating landfills and transfer stations in Alberta.

[12] EPA Victoria (2015): Best Practice Environmental Management, Siting, Design, Operation and Rehabilitation of Landfills. EPA Victoria, Southbank. www.epa.vic.gov.au/our-work/publications/publication/2014/october/788-2

[13] Goorah S.S. Esmyot M.L., Boojhawon R. (2009): The health impact of nonhazardous solid waste disposal in a community: the case of the Mare Chicose landfill in Mauritius. Journal of Environmental Health 72(1):48-54

[14] Gorsevski P.V., Donevska K.R., Mitrovski C.D., Frizado J.P. (2012): Integrating multi-criteria evaluation techniques with geographic information systems for landfill site selection: A case study using ordered weighted average. Waste Management 32(2):287-296

[15] James, S. C. (1977): Metals in municipal landfill leachate and their health effects, $\|$ American Journal of Public Health, vol. 67, no. 5, pp. 429-432, 1977.

[16] Kanmani, S. and Gandhimathi, R. (2013): Assessment of heavy metal contamination in soil due to leachate migration from an open dumping site. Applied Water Science, vol. 3, pp. 193-205, 2013.

[17] Kim K.H., Pal R., Ahn J.W., Kim Y.H. (2009): Food decay and offensive odorants: a comparative analysis among three types of food. Waste Management. 29(4):1265-1273

[18] Komilis D. P., Ham R. K. and Stegmann R, 2009. The Effect of Municipal Waste pretreatment on landfill behaviour: a literature review. Waste Management and Research. Volume 17, Issue 1, pp 10-19

[19] Looser M.O., Parriaux A., Bensimon M. (1999): Landfill underground pollution detection and characterization using inorganic traces. Water Resources. 33(17):3609-3616

[20] Magaji J. Y. (2012): Effects of waste dump on the quality of plants cultivated around Mpape Dumpsite FCT Abuja, Nigeria. Ethiopian Journal of Environmental Studies and Management Vol. 5 No. 4 (suppl. 2) 2012. Pg $567-573$

[21] Modin, H. (2012): Modern landfill leachates; quality and treatment, $\mathrm{PhD}$ dissertation, Lund University.

[22] Moghaddas N.H., Namaghi H.H. (2011): Hazardous Waste Landfill site Selection in Khorasan Razavi Province, Northeastern Iran. Arab Journal of Geoscience 4(1-2):103-113

[23] Mohee R. and N. Soobhany, (2014): "Comparison of heavy metals content in compost against vermicomposting of organic solid waste: past and present," Resources, Conservation and Recycling, vol. 92, pp. 206-213.

[24] Simsek C., Kincal C., Gunduz O. (2006): A solid waste disposal site selection procedure based on groundwater vulnerability map $\neg$ ping. Environ Geology 49(4):620-633

[25] Sumathi V.R, Natesan U, Sarkar C. (2008): GIS-based approach for optimized siting of Municipal Solid Waste Landfill. Waste Management. 28(11): 2146-2160

[26] Waste and Resources Action Programme (WRAP), (2012): Energy from waste Development Guidance. Available at: http://www.wrap.org.uk/sites/files/wrap/O_and EFWGuidance

\section{AUTHORS}

First Author - Magaji J.Y, Department of Geography and Environmental Management, University of Abuja, Authors email: john.magaji@uniabuja.edu.ng 
